\title{
Fostering Students' Cognitive Achievement in Chemistry Through Student - Directed Concept Maps and Demonstration Strategies of Secondary Schools in Ogun State Nigeria.
}

\author{
Sewanu, Bankole, Isaac A. \\ Ogun State Institute of Technology, Igbesa, Ogun State Nigeria. \\ Department of Science Laboratory Technology, \\ E-maill: ibankole 2015@gmail.com
}

\begin{abstract}
This study focuses on fostering students' cognitive achievement using students-concept maps and demonstration in chemistry. A pre-test, post-test control groups $3 \times 3 \times 2$ factorial design was employed. A total of two hundred and forty eight senior secondary two students drawn from three public secondary schools in Ogun state of Nigeria participated in the study. Stratified random sampling technique was used in drawing the schools. Intact classes of students were used for the study. Three research questions and three hypotheses guided the study. Treatment that lasted for four weeks involved teaching redox reaction concepts to experimental groups using students-directed concept mapping, demonstration while the control group was taught using lecture method. Test of Knowledge in Redox Reaction (TKRR) was the instrument for data collection. Mean and standard deviation were used to answer the research questions while the hypotheses were tested with Analysis of covariance (ANCOVA). Results revealed that there was significant difference in the cognitive achievement of students taught using students-directed concept mapping, demonstration and lecture method. Experimental groups' achievement was significantly better than those taught using lecture method. Also ability level is significant factor on students' cognitive achievement in Redox reaction. However, no significant difference was found on the effect of gender on cognitive achievement. Based on the findings, the use of students-directed concept mapping and demonstration strategies to foster cognitive achievement in difficult concept like Redox reaction in chemistry was recommended to chemistry teachers.
\end{abstract}

Keywords: Concept mapping, Demonstration, Chemistry teaching and cognitive achievement.

Aims Research Journal Reference Format:

Sewanu, B.I.A. (2018): Fostering Students' Cognitive Achievement in Chemistry Through Student - Directed Concept Maps and

Demonstration Strategies of Secondary Schools in Ogun State Nigeria. Advances in Multidisciplinary Research Journal. Vol. 4. No.

2, Pp 1-12.

\section{INTRODUCTION}

Science is an organized body of knowledge in form of concepts, laws, theories and generalizations. The body of knowledge in science includes chemistry, biology, physics, pharmacy, and medicine to mention a few. Chemistry is basic to the study of both pure and applied science hence doctors, pharmacists, engineers, agriculturalists and all other science oriented professions at their secondary school level offer chemistry. It is introduced into the curriculum content of secondary school because of its educational value, relevance to the needs of the individual and the society. In a more simple term the knowledge of chemistry has enabled us to produce good water, food, and health care delivery, various materials for the construction of industries, roads, automobiles and houses. Despite the relevance of knowledge of chemistry to the society, achievements of student in chemistry have been very poor (WAEC, 2011-2013; Bankole, 2016). This is detrimental to the development of chemistry in Nigeria. 
Many studies have been carried out in an attempt to establish the causes and probably provide solutions to this problem but not much have been achieved since chemistry students at the secondary level continue to perform poorly. Some of such studies bothered on location of schools, teachers', students' and schools' characteristics, and teaching method among others (Ogunleye and Babajide, 2011). Despite the efforts by researchers to improve science teaching, science teachers (Chemistry inclusive) in Nigerian schools still revert to the use of "chalk and talk" method for teaching rather than interactive and investigative approaches (Longjohn, 2011 ; Omoifo , 2012). There is need for proper delivery of chemistry curriculum at senior secondary schools. It is only when concepts are not meaningfully understood by student that they shy away from questions set on them during SSCE hence poor cognitive achievement in these areas vis-à-vis the overall cognitive achievement of students in chemistry at SSCE. Omoifo (2012) summaries it all by saying our science lessons are yet to be structured, guided and students directed. Talking about low cognitive achievement in science, some topics have been identified difficult for students to learn as a result of the way such concepts are presented to students.

These include: mole concept, Redox reaction, calculations involving volumetric analysis, calculations in electrolysis and calculations involving chemical equations among others (WAEC Chief Examiners reports 2011 - 2015; Okebukola et al 2015). Teachers need to vary instructional strategies so as to present concepts to students in a meaningful manner. These instructional strategies are approaches teachers adopt to lead students in achieving the capabilities (learning outcomes or terminal behaviours) desired of them (Bankole, 2016). There are varieties of instructional methods for science teaching. These include the lecture (talk-chalk), guided discovery, demonstration, discussion, project, Laboratory/Investigative method, cooperative, problem solving, field trips among others (Ajewole \& Owolabi, 1999) . In addition to the above list is meta cognitive tools; Concept Circle diagram, Concept Maps, and Vee Diagrams (Novak\&Gowin, 1984). All these methods rely basically on student oriented techniques, which makes learning meaningful. However, some are more activity oriented than others. In all these, the students accumulate the products of science by vigorously engaging in various processes of science.

Concept mapping is a meta-learning strategy based on the Ausubel-Novak- Gowin theory of meaningful learning (Ausubel, Novak \& Hanesian, 1978; Gowin, 1981;Novak, 1977; Novak \& Gowin, 1984). It is one of the meta-cognitive strategies that empower the learner to take charge of his/her own learning in a meaningful way (Ezenwa ,1996; Jegede et al,1990; Novak,1983). It relates directly to such theoretical principles as prior knowledge, subsumption, progressive differentiation, cognitive bridging, and interrogative reconciliation. Ausubel advocates the use of advanced organizer which is based on the idea that the teacher gives a short description of the new material before the lesson to prepare the student to accept the new material (Reece and Walker, 2003). Meta-cognitive strategies, including meta-knowledge and meta-learning, are strategies that empower a learner to take charge of his/her own learning in a highly meaningful fashion (Jegede et al., 1990; Novak,1983).

Meta knowledge refers to knowledge that deals with the very nature of learning, or learning about meaningful learning (Novak \& Gowin, 1984) or, as defined by Biggs, A concept map is a graph structure containing nodes that are interlinked by labeled, directed arcs. Concepts maps can be used as a knowledge representation tool to reflect relationships that exist between concepts that reside within an individual's long-term memory (Bankole, 2018). When constructing a concept map, the focus is on the relationships among concepts. The combination of two concepts connected by a linking line and labeled by a linking word creates a proposition, which is the smallest linguistic unit that carries meaning (JacobsLawson \& Hershey, 2002). Although a concept map is normally regarded as a network structure, in order to aid learning and understanding, sections of a given concept map can be regarded as hierarchical treelike structures. When a concept map is organized in a hierarchical fashion, the more general and more inclusive concepts should be at the top of the map, with progressively more specific (and less inclusive concepts) arranged below them (Novak \& Gowin,1984). The hierarchical attribute of a concept map also makes meaningful learning proceed more easily as new concepts or concept meanings are subsumed under broader, more inclusive concepts (Novak \& Gowin, 1984). In addition to concepts and labeled links, a concept map can contain another type or labeled link called a cross link. 
Cross links connect two segments of a concept hierarchy. The inter-connective nature of cross links serves an important integrative function when constructing a map (Bankole, 2018).Concept map is visualized through a graphical representation. Concepts are usually depicted by circles or boxes, forming the nods of the new work by labeled links (Buzzetto and More 2007). Juall and Moyet (2005) maintain that concept maps are an educational technique that uses diagrams to demonstrate the relation of one concept or situation by linking a central concept to another one, to help the learners to understand the central concept better. So concept maps are presented as a pyramids seen from above and they are arranged hierarchically with the super ordinate concept at the top of the map and subordinate at the bottom which are less inclusive than higher ones (Ahlberg and Vukko 2004). Novak and Canas (2006) see that concept maps are graphical tools for organizing and representing knowledge. They include concepts closed in circles or boxes of some types and relationships between concepts indicated by connecting or linking two concepts or words on the line referred to as linking words or linking phrase. A well-constructed and competed concept map, thus show the clear relationship between various sets of concepts and thus basic relationship is well communicated to other persons. A finished concept map is analogous to a road map with every concept depending on others for meaning.

Thus, in a concept mapping exercise, students should:

- $\quad$ Note the key words/concepts. Phrases or ideas that are used during the lesson or read in a text;

- $\quad$ Arrange the concepts and main ideas in a hierarchy from the most general, most inclusive and abstract (super-ordinate) to the must specific and concrete (subordinate);

- $\quad$ Adopt or use raw circles or eclipses around the concepts;

- $\quad$ Connect the concepts (in circle) by means of lines or arrows accompanied by linking words so that each branch of may can be read from the top to the bottom;

- $\quad$ Provide examples, if possible, at the terminus of each branch; and

- $\quad$ Cross-link hierarchies or branches of map where appropriate (Okebukola and Ahove, 1994, Bankole, 2016).

Its effectiveness across discipline and career was also available in literature. Its use in the teaching and learning of difficult concepts in sciences, though very few in chemistry has been found (Okafor \& Okeke, 2006; Ezekannagha, 2007; Bou jaoude \& Attieh,2008; Karakuyu,2010, Okebukola,2015). Demonstration method of teaching is the act of teaching by displaying of the instruction situation with an audio- visual explanation of an idea, process or product. It involves showing, doing and telling the students the point of emphasis. There are two styles. Lecture demonstration and demonstration performance method. A lecture demonstration method is a teaching technique that combines oral explanation with "doing" to communicate processes, concept, and facts. It is particularly effective in teaching skills that can be observed. A skilled educator may wish to both tell and show what steps to take in an educational process. A demonstration is usually accompanied by a thorough explanation, which is essentially a lecture. On the other hand, the demonstration performance method of teaching is based on the simple but sound principle that we learn by "doing". Students learn physical or mental skills in actually performing those skills under supervision. Studies revealed that demonstration enhances students learning in the separation of mixtures (Agboola \& Oloyede,2012).

This makes it imperative to beam the searchlight on an approach for teaching chemistry that aims at enhancing understanding rather than promoting memorizing and juggling of facts. An effective way of dealing with this problem is for the teacher to provide a bridge between the familiar concepts and the knowledge which students are yet to acquire. It is clear that there is need to seek other methods of teaching that will be student centered, involving critical thinking, make learning meaningful and improve achievement. These teaching strategies may include student - directed concept maps and demonstration strategies. In these strategies, students are expected to be engaged in activities in which they can interact with each other. This study therefore investigated the use of students-directed concept maps and demonstration to foster cognitive achievement in chemistry. 


\subsection{Research questions}

(i) Will cognitive achievement of students taught redox reaction using students - directed concept maps, demonstration teaching strategies better than those taught using lecture method?

(ii) Are the male's cognitive achievements in redox reactions better than that of their female counterparts using students- directed concept maps, demonstration teaching strategies?

(iii) Does the cognitive achievement of high, average and low achievers in redox reaction significantly differ using either student directed - concept maps, or demonstration and lecture teaching strategies?

\subsection{Hypotheses}

The following hypotheses were tested at 0.05 significance level.

Ho1: There is no significant difference in the cognitive achievement of students in redox reaction using students-directed concept maps, demonstration and lecture teaching strategies.

$\mathrm{Ho}_{2}$ : There is no significant difference in the cognitive achievement of male and female students taught using students-directed concept maps, demonstration or lecture teaching strategies.

$\mathrm{Ho}_{3}$ : There is no significant difference among the cognitive achievement of high, average and low ability students taught using student - directed concept maps, demonstration and lecture teaching strategy.

\section{RESEARCH DESIGN}

The study adopted quasi-experimental research design. A pre-test, post-test non randomized control groups $3 \times 3 \times 2$ factorial design was employed. In this design three teaching strategies (students directed concept mapping, demonstration, and lecture) were crossed with students' ability levels (high, average and low in chemistry) and students' gender (male and female). Intact class was used because it was not possible to randomly assign students to experimental and control conditions because of the administrative set-up of the schools.

\subsection{Sample and Sampling Techniques}

The population of the study consisted of Ogun state senior secondary school II chemistry students. A total of two hundred and forty eight students (113 Female and 135 male) from six public secondary schools in six Local governments in Ogun state, Nigeria participated in the study. Stratified random sampling technique was used in drawing the schools. These subjects were chosen because they were readily available for the study since they were not preparing for the Senior Secondary Certificate Examination (SSCE) unlike the SSS III students. Also they have studied chemistry for at least a school year.

\subsection{Instrumentation}

A research instrument, Test of Knowledge of Redox Reaction (TKRR) was used to collect data for the study. TKRR is a thirty five minutes test. It is a thirty item multiple choice objective test with four options per item. The items were drawn from past questions of Chemistry curriculum of Senior Secondary Certificate Examination SSCE, National Examination Council and Joint Admission Examination and Matriculation Board. The items selected were those constructed around the knowledge, comprehension and application sub-levels of Bloom's cognitive domain.

A total of forty nine items were initially selected covering the concepts in Redox reaction. The items were given to two senior secondary two (SSII) chemistry teachers; two science educators who are knowledgeable in test construction who subjected these items to scrutiny and content validation. The items were moderated and the language used was modified to suit that of SS II students. A total of thirty eight items was later returned. Thirty out of the thirty eight were randomly selected and was trial tested by administering it on 80 students, 48 boys and 32 girls of a similar secondary school which does not involved in the study. These students were similar in class and age range of $14-17$ years to those for whom the instrument was finally used. The responses were scored by awarding one point to each correct response and zero for a wrong response. Thereafter, the difficulty indices of each of the items were calculated. The items with difficulty indices between 0.48 and 0.70 were selected. 
This was to ensure the items were neither too difficult nor too easy for the subjects. The reliability of the test was determined using the SPSS version 17 on the responses of the sample and the split half computed value was found to be 0.847 .

\subsection{Procedure.}

The research team consisted of the researcher and six research assistants (chemistry teachers) from the participating schools. They were trained for three weeks on the use of the instructional strategies adopted in the study. This was done to ensure that all the teachers involved in the study adhered to the standard of the study. To ensure that there was as much uniformity in the presentation of the content on the chosen topic; the researcher met with all the three teachers involved and issued them with instructional guide specifically designed for the topic of Redox reaction to enhance their adherence to the treatment conditions. The same schemes of work were adopted by the teachers to ensure that the intended content was covered uniformly for all the groups involved in the study. Data was collected in two stages. The pilot stage (trial) pretest data was collected by the administration of TKRR to the two experimental groups and the control group in their intact classes. The pretest data allow for categorization into ability level of high, average and low levels. The treatment was then administered for a period of five weeks. The experimental groups 1 and 2 were taught Redox reaction contents with concept mapping strategy and demonstration teaching strategy respectively. The control group was taught using lecture teaching method. A week after the treatment period, a posttest was administered by the researcher with the help of the subject teachers in the three schools. The data collected were analyzed using mean, standard deviation and Analysis of covariance (ANCOVA).

\section{RESULT OF FINDINGS.}

Data for answering research questions were obtained by computing the pre-test and posttest mean and standard deviation (SD) scores of the students, while the Analysis of covariance (ANCOVA) was used to test the null hypotheses at 0.05 level of significance with the pre- test scores as covariance.

\section{Research Question 1}

Will cognitive achievement of students taught redox reaction be significantly better using students directed concept maps, demonstration teaching strategies than those taught using lecture method?

Table 1: Post test mean and standard deviation scores of students' cognitive achievement due to teaching methods.

\begin{tabular}{|l|l|l|l|l|l|l|}
\hline Method & $\mathrm{N}$ & $\begin{array}{l}\text { Pre -test } \\
\text { mean }\end{array}$ & $\begin{array}{l}\text { Post test } \\
\text { mean }\end{array}$ & $\begin{array}{l}\text { Pretest } \\
\text { standard } \\
\text { deviation }\end{array}$ & $\begin{array}{l}\text { Post test } \\
\text { standard } \\
\text { deviation }\end{array}$ & Mean gain \\
\hline SDCM & 77 & 6.75 & 26.21 & 2.92 & 3.04 & 19.46 \\
\hline DM & 84 & 6.52 & 18.68 & 2.57 & 3.08 & 11.16 \\
\hline LM & 87 & 6.85 & 14.48 & 2.87 & 3.71 & 7.63 \\
\hline
\end{tabular}

The result in table 1 showed that the mean pre-test scores of all the groups were almost equal but the mean posttest score of students taught using students- directed concept mapping strategy was higher 26.21 than that of the demonstration strategy group which had 18.68 and the lecture method group with the posttest means score of 14.48. The concept mapping group (experimental group) had a precognitive post cognitive gain of 19.46 which is higher than that of the demonstration group with a gain of 11.16 and the control group with the least gain of 7.63. This indicates that experimental group which is exposed to students-directed concept mapping strategy gained more compared to their counterparts in the demonstration and control group exposed to lecture method. To further answer the research question 1 , hypothesis 1 was tested at 0.05 level of significance. 


\section{Hypothesis one $\left(\mathrm{H}_{01}\right)$}

There is no significant difference in the cognitive achievement of students taught redox reaction using students-directed concept maps, demonstration and lecture teaching strategies .

Table 2: ANCOVA result of test between subjects effects

Dependent Variable :post-test cognitive

\begin{tabular}{|l|l|l|l|l|l|}
\hline Source & $\begin{array}{l}\text { Type III Sum of } \\
\text { Squares }\end{array}$ & Df & Mean Square & F & Sig. \\
\hline Corrected Model & $6083.901^{a}$ & 3 & 2027.967 & 214.431 & .000 \\
Intercept & 9248.893 & 1 & 9248.893 & 977.951 & .000 \\
Pre-test cognitive & 373.110 & 1 & 373.110 & 39.452 & .000 \\
Method & 5797.538 & 2 & 2898.769 & 306.507 & .000 \\
Error & 2307.611 & 244 & 9.457 & & \\
Total & 103123.000 & 248 & & & \\
Corrected Total & 8391.512 & 247 & & & \\
\hline
\end{tabular}

a. $\mathrm{R}$ Squared $=.725$ (Adjusted R Squared $=.722$ )

The result in table 2 shows that $\mathrm{F}_{(2,244)}=306.51 ; \mathrm{P}<0.05$. This result indicates that teaching strategies had a significant difference in cognitive achievement in Redox reaction. Thus, the hypothesis of no significance difference is rejected. The experimental groups (students-directed concept mapping and demonstration group) had a higher cognitive achievement in redox reaction than those taught using the lecture method. Furthermore, the methods has contributed $72.5 \%$ in variance to the cognitive achievement of students in redox reaction but when adjusted the contribution was reduced to $72.2 \%$. To account for the difference between the groups Bonferroni pair wise comparisons was conducted. The result shows that students directed concept mapping strategy (SDCM) accounted for the difference to demonstration method (DM) and lecture method (LM).

\section{Research Question 2}

Are the male's cognitive achievements taught redox reactions better than that of their female counterparts using students- directed concept maps, demonstration teaching strategies?

Table 3: Mean and standard deviation of male and female subject.

\begin{tabular}{|l|l|l|l|}
\hline Sex & Mean & Standard deviation & N \\
\hline Male & 19.21 & 6.41 & 135 \\
\hline Female & 19.95 & 5.04 & 113 \\
\hline Total & 19.54 & 5.83 & 248 \\
\hline
\end{tabular}

Table 3 reveals that the mean score of posttest on cognitive achievement of female students in the study is slightly higher $(x=19.95)$ than that of male students $(x=19.41)$. The implication of this is that female cognitive achievement is slightly better than male when taught redox reaction using the teaching strategies. To further verify this, hypothesis 2 was tested. 


\section{Hypothesis 2}

There is no significant difference in the cognitive achievement of male and female students taught using students-directed concept maps, demonstration or lecture teaching strategies.

\section{Table 4: Tests of Between-Subjects Effects}

Dependent Variable: post-test cognitive

\begin{tabular}{|l|l|l|l|l|l|}
\hline Source & $\begin{array}{l}\text { Type III Sum of } \\
\text { Squares }\end{array}$ & df & Mean Square & F & Sig. \\
\hline Corrected Model & $294.912^{\mathrm{a}}$ & 2 & 147.456 & 4.462 & .012 \\
Intercept & 9294.992 & 1 & 9294.992 & 281.263 & .000 \\
Pre-test cognitive & 261.274 & 1 & 261.274 & 7.906 & .005 \\
Sex & 8.550 & 1 & 8.550 & .259 & .611 \\
Error & 8096.600 & 245 & 33.047 & & \\
Total & 103123.000 & 248 & & & \\
Corrected Total & 8391.512 & 247 & & & \\
\hline
\end{tabular}

a. $\mathrm{R}$ Squared $=.035$ (Adjusted $\mathrm{R}$ Squared $=.027$ )

Result in table 4 revealed that the cognitive achievement of male and female students in the study do not differed significantly $\left[F_{(1,245)}=0.259 ; p>0.05\right]$ when taught Redox reaction using students-directed concept maps, demonstration or lecture teaching strategies.

Therefore the hypothesis of no significant difference in the cognitive achievement of male and female students taught using students-directed concept maps, demonstration or lecture teaching strategies is not rejected. 


\section{Research Question 3}

Does the cognitive achievement of high, average and low achievers taught redox reaction significantly differ using either student directed - concept maps, or demonstration and lecture teaching strategies?

Table 5: Posttest mean and standard deviation of students' cognitive achievement scores of high, average and low ability students taught using students-directed concept mapping, demonstration and lecture teaching strategies

\section{Table 5: Descriptive Statistics on ability levels.}

Dependent Variable :post-test cognitive

\begin{tabular}{|l|l|l|l|}
\hline ability level & Mean & Std. Deviation & N \\
\hline High & 22.2963 & 5.11981 & 54 \\
Average & 18.6966 & 5.59057 & 145 \\
Low & 19.0204 & 6.41447 & 49 \\
Total & 19.5444 & 5.82870 & 248 \\
\hline
\end{tabular}

Table 5 reveals that high ability level students had high post test mean $(22.30)$ followed by low ability level with post test mean of 19.02 while the average ability level students had post test mean of 18.70. The implication was that ability level foster cognitive achievement of the students. This was further verified by testing hypothesis 3 .

\section{Hypothesis 3}

There is no significant difference among the cognitive achievement of high, average and low ability students taught using student - directed concept maps, demonstration and lecture teaching strategy.

Table 6 : Tests of Between-Subjects Effects for students' cognitive achievement scores of high, average and low ability students taught using students-directed concept mapping, demonstration and lecture teaching strategies.

Dependent Variable: post test cognitive

\begin{tabular}{|l|l|l|l|l|l|}
\hline Source & $\begin{array}{l}\text { Type III Sum of } \\
\text { Squares }\end{array}$ & Df & Mean Square & F & Sig. \\
\hline Corrected Model & 526.639 & 3 & 175.546 & 5.446 & .001 \\
Intercept & 2062.020 & 1 & 2062.020 & 63.972 & .000 \\
Pre test cognitive & .014 & 1 & .014 & .000 & .983 \\
Ability level & 240.276 & 2 & 120.138 & 3.727 & .025 \\
Error & 7864.873 & 244 & 32.233 & & \\
Total & 103123.000 & 248 & & & \\
Corrected Total & 8391.512 & 247 & & & \\
\hline
\end{tabular}

a. $\mathrm{R}$ Squared $=.063$ (Adjusted R Squared $=.051$ )

The result in table 6 indicates that ability level is significant factor on students cognitive achievement $\mathrm{F}$ $(2,244)=3.73 ; \mathrm{P}<0.05$. Therefore, the hypothesis of no significant difference among the cognitive achievement of high, average and low ability students in Redox reaction when they were taught using student - directed concept maps, demonstration and lecture teaching strategy is rejected. 


\section{DISCUSSION OF RESULTS.}

Results in table1 show that the mean pre-test scores of all the groups were almost equal but the mean posttest score of students taught using students- directed concept mapping strategy was the highest (26.10) and that of the demonstration strategy group was higher(18.68) and the lecture method group was the least (14.48). The concept mapping group (experimental group) had a precognitive post cognitive gain of 19.46 which is higher than that of the demonstration group with a gain of 11.16 and that of the control group with the least gain (7.63). This indicates that experimental group which is exposed to students-directed concept mapping strategy gained more cognitive achievement compared to their counterparts in the demonstration and control group exposed to lecture method. This is confirmed in table 2 which indicates that method of teaching had a significant effect on cognitive achievement in Redox reaction. The experimental groups (students-directed concept mapping and demonstration group) had a higher cognitive achievement in redox reaction than those taught using the lecture method.

Furthermore, the method has contributed $72.5 \%$ in variance to the cognitive achievement of students in redox reaction but when adjusted it was reduced to $72.2 \%$. This is in line with the findings of previous studies (Uchenna \& Okafor, 2012, Bankole, 2016) which provided evidence attesting to the effectiveness of concept mapping in fostering cognitive achievement through meaningful learning. The reason for the better cognitive achievement of students in the concept mapping and demonstration (experimental groups) is that they were able to link the new concepts to the previous concepts they have come across previously. In addition, they were able to interact with one another clarifying concept from one another. Tables 3 and 4 reveal that the female and male subjects in this study had almost equal pretest and posttest mean score. This situation is confirmed by the pretest-posttest gains. The implication of this is that male cognitive achievement is not better than female when taught redox reaction using the teaching strategies in the study. This is in line with the findings of Olorundare, A.S \& Aderogba, G.A (2009); Fatokun, \& Eniayeju, P.A (2014).

However, the finding is contrary to that of Okebukola \& Jegede 1990; Kelly, 2007; Udeani, 2012. They found a reduced gap between male and female performance in science. Tables 5 and 6 show clearly that ability level of students has a great impact on the cognitive achievement in difficult chemistry concept such as Redox reaction and that having students construct their learning using the concept mapping strategy and demonstration foster achievement in chemistry. 


\section{CONCLUSIONS.}

The findings of this study revealed that the use of students-directed concept maps and demonstration teaching and learning strategies enabled students to achieve better than using lecture method. This is because these strategies are innovative, interactive and student centered. It also allows manipulation and mapping that cut the attention of the students as they construct maps. Gender has no effect on the achievement of students as they learn using concept mapping and demonstration strategies. In other words male and female are favoured in the use of the strategies. It is gender friendly. However, ability level had a significant difference in the cognitive achievement of students in Redox reaction.

The following recommendations were made based on the findings of the study.

1. Since students-directed concept mapping and demonstration strategies were found to foster cognitive achievement of students in chemistry, chemistry teachers should adopt these strategies in teaching difficult concept such as Redox reaction in chemistry classroom.

2. Science text book writers especially chemistry should use concept mapping to illustrate concept in chemistry textbooks.

3. Government should as a matter of urgency organize refresher courses, workshops and conferences for science teachers to update their knowledge on the innovative teaching strategies that can foster students' cognitive achievement . 


\section{REFERENCES}

1. Agboola, O. S. \& Oloyede, E. O. (2012). Effects of project, inquiry and lecture-demonstration teaching methods senior secondary students' achievement in separation of mixtures practical test. Educational Research and Review Vol. 2 (6), pp. $124-132$.

2. Ahmed, O. Q. (2010). The effect of using concept mapping in teaching on the achievement of fifth graders in science. Stud Home Comm. Sci., 4(3): 155 - 160.

3. Ameh, P. O. \& Dantani, Y. S. (2012). Effects of Lecture and Demonstration methods on the academic achievement of students in Chemistry in Nassarawa Local Government area of Kano State. International Journal of modern social sciences, 1 (1); pp. $29-37$.

4. Ausubal, D. P. Novak, J. D. \& Hanesian, H. (1978). Educational Psychology: A cognitive view, $2^{\text {nd }}$ ed, New York: Holt, Rinehart and Winston.

5. Bankole, I.A.S (2013). The impact of concept mapping and cooperative strategies on the learning of senior secondary school chemistry students in Ado - odo/Ota local government area of Ogun state. Journal of Educational Research Vol.21 no 3, 22-30.

6. Bankole, I.A.S (2016). Impact of card games on cognitive achievement of Senior Secondary Chemistry. Journal of the Faculty of Education, Lagos State University, Lagos, Nigeria. Educational Perspective, vol.10 no 1 , pp. 55-70.

7. Bankole , I.A.S (2018). Deploying card games as tools in learning chemistry concepts in Nigerian Classrooms. Journal of Chemical society of Nigeria. Vol.43 issue 3. pp

8. Barchuk, K. H.; Too, J. K. \& Ngemo, K. J. (2013). Effect of collaborative concept mapping teaching strategy on students' attitudes towards chemistry in selected secondary schools in Kenya. Aisian Journal of social sciences and humanities, vol. 2 (2) pp $530-540$.

9. Bosede , A.F. (2010). Influence of sex and location on relationship between student problem and academic performance. The social science 5(4),340-345.

10. Buzzetto-More, N. A. (2007). Advanced Principles of Effective E-learning. Califonia Information Science Press.

11. Daluba, N. E. (2013). Effect of Demonstration method of teaching on students' achievement in Agricultural Science. World Journal of Education, vol. 3 (6), $1-7$.

12. Dantani, I, W.; Kure, I. D. \& Hasssan, U. (2013). Comparative analysis of Hierarchy and spider modes of concept mapping on secondary school students' achievement in mathematics in Niger State, Nigeria. International Journal of Humanities and social science invention. www.ijhssi.org volume 2 issue 71 , pp. $13-16$.

13. Ekpo, B.B.(2006). Tip on teaching difficult concept in senior secondary school chemistry. Review of education. Institute of education, university of Nigeria Nsukka.

14. Ezekannagha, G.N. (2007). Effects of concept mapping and cognitive styles on achievement of students in integrated science. Unpublished Ph.D Thesis. University of Nigeria Nsukka.

15. Ezenwa, V. I (1996). A comparative study of the effectiveness of concept-mapping and guided discovery teaching strategies on secondary school students' understanding of selected chemistry concepts. Unpublished Ph.D Thesis Dept. of Education Ahmadu Bello University, Zaria.

16. Gowin, D. B. (1998). Educating. Ithaca, NY: Cornell University Press.

17. Ibe, E. \& Nwosu, A. A. (2003). Effects of Guided-inquiry and demonstration on science process skills acquisition among secondary school biology students. Journal of the science teacher association of Nigeria. Vol. 38, (1 \&2), pp. $58-63$.

18. Igboegwu, E. N. \& Egbutu, R. N. (2011). Effects of co-operative learning strategy and demonstration method on acquisition of science process skills by chemistry students of different levels of scientific literacy. Journal of Research and development, Vol. 3 (1); pp $204-212$.

19. Jegede, S.A. (2007). Students 'anxiety towards the learning of chemistry in some Nigerian secondary schools. Educational Research and Review 2(7) 193-197.

20. Kelly, G. J. (2007). Discourse in science classrooms in S. K. Abel \& N. G. Laderman (Eds). Handbook of research on science education. Malawi NJ: Lawrence Erlbaum.

21. Levis, B. E. (2006). Content, context, currency, critique and conduct: A transformative prescription for African Science Education. San Francisco: American Educational Research Association. 
22. Meyer, J. H. F. \& Shannahan, M. P. (2004). Development meta learning capacity in students: Actionable theory and practical lessons learned in first year economics. Innovations in Education and Teaching International, $41 \mathrm{pp} 443-455$.

23. Njoku, Z.C (2003). Enhancing girls acquisition of science process skills in educational schools : An experience with sex-grouping for pratical chemistry. Journal of STAN,37(1\&2).

24. Novak, J. D. (1977). A Theory of Education. Ithaca., NY: Cornell University Press.

25. Novak, J. D. \& Canas,A. J. (2006). The Theory underlying concept map and how to construct them. From http//camplihanc/us/publications Researchpapers/Theory campus/theoryunderlying conceptsmaps.html.

26. Novak, J. D. \& Gowin, D. B. (1984). Learning how to learn. New York: Cambridge University Press.

27. Novak, J. D., Godwin, D. B. \& Johnson, G. T. (1983). The use of concept mapping and knowledge vee mapping with junior high school science students, science education. 67 (5), pp. $625-645$.

28. Okebukola, P. A. O. \& Ahove, M. A. N. (1994) in Oke (2003) comparative effectiveness of concept mapping and reading-plus-annotation teaching strategies on students' performance in ecology. Unpublished Ph.D Thesis, Lagos State University, Ojo, Lagos.

29. Okebukola,P.A.O et al (2015)Survey of E-learning readiness of facilities, Principals/Teachers and Students in Lagos state senior secondary schools. LASG-LASU E-learning Project team. www.lasgelearning.org.

30. Okeke, E.A.C.(2008). Clarification and analysis of gender concept. Focus on Research, Reproductive Health Education, and gender sensitive classrooms. STAN and STM Education Series No 2; 5-8.

31. Okoh, J.C. (2006). Effects of investigative laboratory approach and expository retrieval of acquisition of science process skills by biology students of different level of scientific literacy. Journal of STAN $41(1 \& 2)$.

32. Olatoye, R. A. \& Adekoya, Y. M. (2010). Effect of project-based, Demonstration and Lecture Teaching strategies on Senior Secondary Students' achievement in an aspect of Agricultural Science. International Journal of Educational Research and Technology, vol. 1 (1) June 2010: pp $19-29$.

33. Olorundare, A. S. \& Aderogba, G. A. (2009). Comparative effects of concept-mapping, Analogy and Expository strategies on Secondary School Students' performance in Chemistry in Ilesa, Nigeria. Journal of Curriculum and Instruction (JCl) vol. 7 (1 \& 2); pp. $112-126$.

34. Oloyede, O. I. (2010). Comparative effect of the Guided Discovery and concept mapping teaching strategies and SSS students' chemistry Achievement. Humanity \& Social Sciences Journal, 5 (1): 1 - 10.

35. Udeani, U., \& Okafor, P. N. (2012). The effect of concept mapping instructional strategy on the biology achievement of senior secondary school slow learners. Journal of Emerging Trends in Educational Research and Policy Studies (JETERAPS). 3 (2): 137 - 114 